\title{
Brutalidade antiga: sobre história e ruína em Euclides
}

\author{
FRANCISCO FOOT HARDMAN
}

\begin{abstract}
“As idéias que as ruínas me despertam são grandes. Tudo se aniquila, tudo perece, tudo passa. Só fica o mundo. Somente o tempo perdura. Como é velho este mundo! Caminho entre duas eternidades. De qualquer parte para onde lanço o olhar, os objetos que me rodeiam me anunciam um fim $\mathrm{c}$ me resignam àquele que me espera. Que é minha existência efềmera, comparada à deste rochedo que se alui, à deste vale que se cava, desta floresta que flutua, dessas massas suspensas acima de minha cabeça e que se abalam? (...) Uma torrente arrasta as nações umas sobre as outras para o fundo de um abismo comum; eu, eu só, pretendo parar na margem e atravessar a corrente que corre a meus lados!"
\end{abstract}

Denis Diderot, Salons (1767)

\section{"Atlântida! Atlântida!}

Onde estão agora as florestas, as torrentes caudais, as cidades, os reinos? Onde os homens, os rebanhos, as feras? Monumentos, grandeza, poderio, exércitos, ciências, e as gloriosas artes? Onde jaz sepultado o gênio humano, fertilizador das regiões desaparecidas? Que é feito das próprias ruínas? Como foram consumidos os venerandos restos da arquitetura - fustes truncados, capitéis caídos? E os túmulos? as ossadas dispersas, que vão ficando das gerações no roteiro dos séculos? A própria morte morreu. $E$ as montanhas, que suspeitávamos eternas, na audaciosa majestade da pedra, familiares entre a águia e o raio, como Júpiter Deus?!"

Raul Pompéia, Os continentes. In: Canções sem metro (1900)

“Anoiteceu: as ruínas de Gizé estenderam-se, severas, para o crepúsculo sem aurora; sim, sim; tudo nelas é expandido: tudo que vem delas - expande-se; e na poeira suspensa, agora acendem-se luzes marrom-escuras; e - está abafado.

E ele se encostou, pensativo, no lado morto de uma pirâmide; ele próprio - é uma pirâmide, o cume de uma cultura que - vai ruir."

Andrei Biéli, Petersburgo (1916)

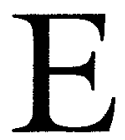

M GERAL, OS ESTUDIOSOS têm ressaltado muito a ideologia do progresso na formação e na obra de Euclides da Cunha. Engenheiro e oficial do exército formado pela Escola Militar, era natural a impregnação de seu pensamento por idéias que perpassavam grandes movimentos político-culturais da época - último quartel do século XIX - em especial, no Brasil: positivismo, evolucionismo, cientificismo, monismo materialista, socialismo reformista, 
republicanismo. Correlata dessa tendência, encontra-se a crença na missão civilizadora da ciência e da técnica, sob os auspícios do Estado nacional.

Não desenvolverei aqui essa questão já por demais analisada (1). Desejo, ao contrário, enfatizar, em oposição a esse quase lugar-comum com respeito ao autor de Os sertões, uma outra polaridade que marca profundamente, a meu ver, toda a sua obra: trata-se de um romantismo de base, de matriz hugoniana, que provoca em sua prosa e poesia uma interessante combinação entre estética do sublime, dramatização da natureza e da história e discurso socialmente empenhado. Matriz essa que não foi propriamente apanágio de Euclides, mas terá penetrado, com amplo espectro, boa parte da produção de nossos primeiros modernos ou antigos modernistas (2). Mesmo em sua forma mais exuberante, $o$ fundo do texto euclidiano permanece eivado do sentimento trágico da solidão humana no mundo e em sociedade. A história, nele, como indicaremos, constitui essencialmente uma construção de ruínas; a obra civilizatória, dado o eterno drama do choque de temporalidades culturais, significa, também, um processo irrefreável de fabricação de desertos. A história desenha-se, afinal, nesse suceder de ruínas precoces, como narrativa materialmente dramática de brutalidades, $o$ homem ainda não tendo se separado de todo dos intempestivos movimentos de certa desordem natural, do movimento caótico e formidável dos elementos primitivos. Romântico realista, talvez, mais do que realista romántico (3), na obra de Euclides localizam-se vários traços dessa unidade dramática em que o tema da ruína - eterno retorno da natureza caótica e violenta sobre o tempo histórico dos empreendimentos civilizados da humanidade - aponta, assim, para a condenação desses últimos ao jogo tumultuário e bruto dos elementos, ao choque babélico entre culturas descompassadas em suas paisagens e épocas (4) e ao encadear trágico de fracassos e incompletudes. Nossas pistas, aqui, remeterão para textos afora Os sertões, anteriores e posteriores à obra-prima euclidiana, em função de terem sido, até hoje, um tanto ofuscados pelo livro-emblema de 1902 e, relativamente à trajetória de sua enorme fortuna crítica, algo menosprezados. É claro, porém, que a representação desse Apocalipse invertido que é Canudos, destruída pelo fogo ateado desde o aparelho de Estado, desse sertanejo secular, um forte, que se consome antes de se formar plenamente do ponto de vista étnico-cultural, a desolação, enfim, dessa paisagem seca, retorcida e violenta, todos esses elementos de uma cólera durápel, dessa Mênis vingativa e inapelável (5), permitiriam, em larga medida, que se buscassem igualmente na obra maior de Euclides os sinais dessa história nada progressiva ou edificante, mas, antes, anfiteatro inacabado e trágico, narrativa de corrosões arcaicas e atuais, história como coleção de ruinarias (6).

Pois se o fogo calcina os místicos de Monte Santo, terra gasta e apta a ser cenário da pólvora devastadora, no outro deserto que fascinou Euclides a partir de uma missão geopolítica nas fronteiras do Alto Purus, em 1905 - a Amazônia 
- são as grandes massas hídricas, em perpétua turbulência, responsáveis pela dispersão dos esforços povoadores e pela impressão geral de paraiso perdido, de inacabamento da paisagem ainda à margem da história, ou mesmo sem história. Ali, o seringueiro solitário esculpe Judas à sua imagem e semelhança para ser tragado na correnteza do rio. Palácios demarcatórios do poder colonial são taperas arruinadas. Tapuios na cidade viram párias. $\mathrm{E}$, na selva, os sinais do extrativismo predatório e nômade são aqueles deixados por esses bandos de construtores de ruinas. Nenhuma civilização, a rigor, lá se fixa. As cidades amazônicas, como os homens, são errantes (7).

Quando em Manaus, Euclides idealizara projeto literário ambicioso em torno dos sertões amazônicos, que seria, segundo ele próprio, sua "segunda vingança contra o deserto". Em carta a Coelho Neto, de março de 1905, afirma: "Nada te direi da terra e da gente. Depois, aí, e num livro: Um paraíso perdido, onde procurarei vingar a Hylaea maravilhosa de todas as brutalidades que a maculam desde o século XvII. Que tarefa e que ideal! Decididamente nasci para Jeremias destes tempos. Faltam-me apenas umas longas barbas brancas, emaranhadas e trágicas." (8)

Tragédia não só por esse messianismo de causas perdidas, mas que se entremeia com o drama pessoal do autor nos últimos anos de vida, premido entre a crise familiar, a burocracia estatal e os dilemas da política diplomática sul-americana. Tragédia das brutalidades contemporâneas que se faziam nos pontos extremos do território, em nome do progresso e da fixação dos marcos do poder do Estado nacional. Por isso, sua visão do seringueiro, embora não tenha forjado a segunda obra-prima imaginada, é bem mais aguda do ponto de vista da questão social. De todo modo, ao retornar do Purus, ainda em Manaus, esboçava um manuscrito que, segundo depoimentos de amigos, depois se perderia em seu projeto original. A julgar, ao menos, pelos sete ensaios sobre temas amazônicos que constituem a primeira parte de $\dot{A}$ margem da história, bem como por outros textos avulsos que publicou sobre a região, o escrito primitivo que ensaiara se desfez no curso da obra e dos acontecimentos; também a história de seu Um paraíso perdido arruinava-se como prosa literária acabada e como manifesto social de intervenção na opinião pública, na trilha de Os sertões. Numa palavra, tratava-se de um discurso interrompido. Firmo Dutra, por exemplo, em artigo-testemunho sobre essas reminiscências amazônicas, registra: "A morte trágica não lhe permitiu rever sua última obra, resultado da observação profunda e da admiração quase explosiva, tão de seu temperamento, pela Hylaea prodigiosa. Daí, ao certo, a razão de não se encontrar no livro um capítulo esboçado, que se intitulava Brutalidade antiga e era a pintura, com as fortes tintas de que sabia usar Euclides, da entrada dos povoadores para os altos rios, deixando atrás de si a devastação dos cauchais e o sulco sangrento das caçadas aos índios" (9). 

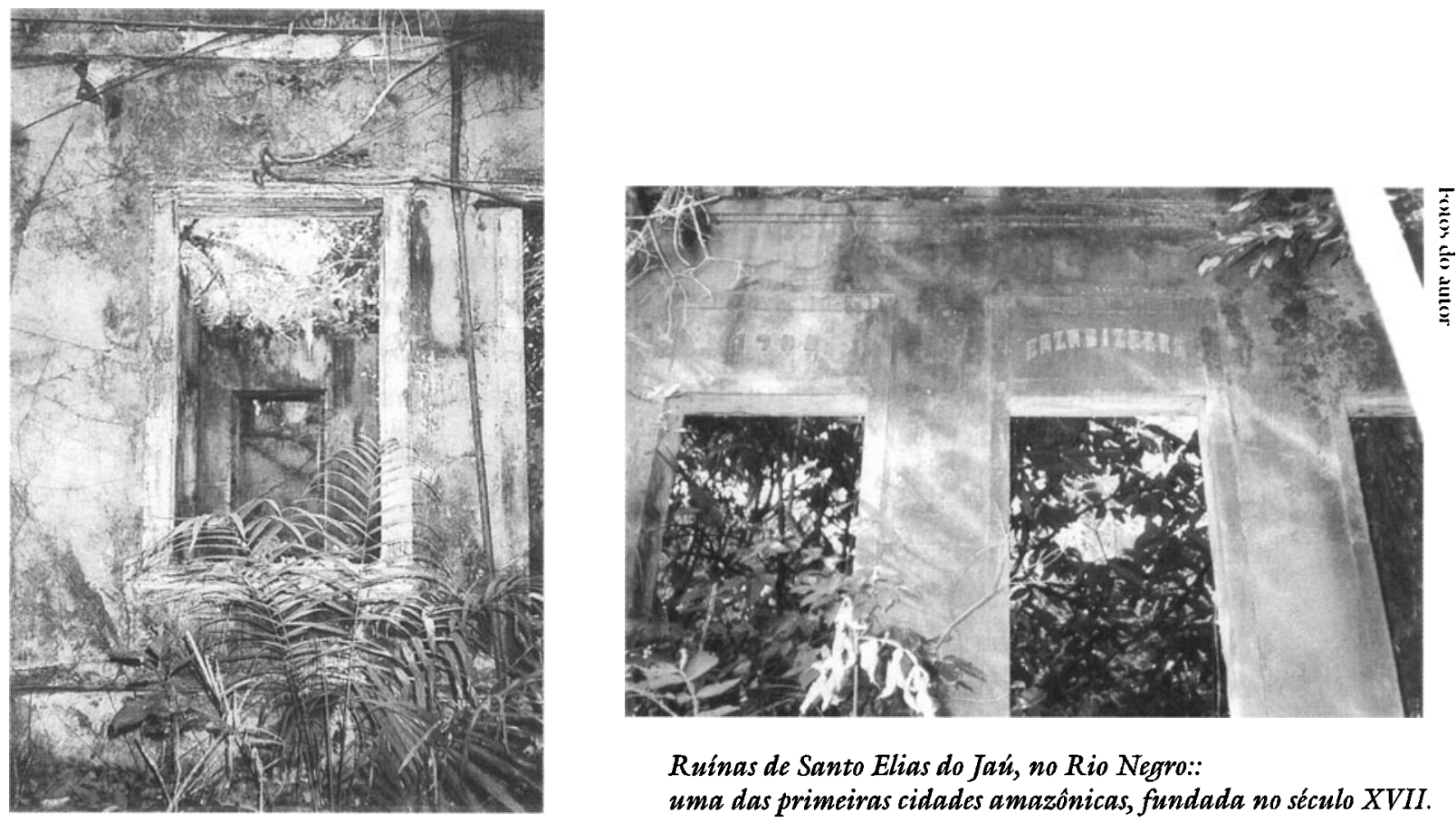

Ruínas de Santo Elias do Jaú, no Rio Negro:: uma das primeiras cidades amazônicas, fundada no século XVII.

A história produtora de ruínas, no entanto, está disseminada pelo conjunto da obra euclidiana. Sua matriz estético-literária está bem longínqua, remetendo, entre outros autores, às obras de Burke e Volney (10), no século XVIII, que terão repercussões por todo o alto romantismo do XrX, chegando até Hugo, com fortes ressonâncias no Brasil (11), alimentando imaginários americanos tão díspares quanto Poe ou Sarmiento, ou rebatendo com ímpeto na obra do visconde de Taunay, leitor direto de Volney (12). Seja pela lateralidade quase mitológica entre Vesúvio e Pompéia, seja pelo tema remoto da iminente vingança da natureza contra as criações humanas, o fato é que se tem associado, com freqüência, vulcanismos geológicos ou revolucionários com imagens de ruínas. Mesmo em Volney, a visão das ruínas da antigüidade oriental figuradas no Egito e na Síria servem de tela de fundo para uma meditação sobre a revolução dos impérios, à luz dos acontecimentos cruciais na França de 1789. E o historiador inglês Buckle, tão lido e citado por Euclides, também terá se inspirado no orientalismo de Volney, em suas representações de paisagens exóticas e materialmente ruinosas, a geografia dos grandes ambientes naturais entrando como componente básico nas transformações históricas (13). Metáforas vulcânicas aparecem, entre nós, por exemplo, em textos menos conhecidos de Raul Pompéia e Gonzaga Duque; e, pouco mais tarde, em Alberto Rangel (14). Já o republicano radical Silva Jardim, levou seu vulcanismo até os limites trágicos da experiência, atraído irresistivelmente pelos segredos do centro da Terra (15). Interessante notar, a propósito, que, no caso de Euclides, tanto Oliveira Lima quanto Araripe Júnior utilizam-se de imagens vulcânicas quando dele se recordam após sua morte (16). 
Essas descargas caóticas de gigantescas massas de materiais elementares, base de agônicas representações - rodamoinhos, erupções, incêndios enormes, maremotos e naufrágios, impulsos e tempestades, raios e furacões, pântanos e correntezas - mal disfarçando sua filiação às figurações românticas da instabilidade e do desequilíbrio, chão movediço do pânico que funda o sublime, remetem a uma natureza perigosa e vingativa, vampiro da razão, no movimento de eterno retorno de um princípio destrutivo de toda história racional (17).

Vale anotar, de passagem, alguns textos sugestivos da sedutora vinculação de Euclides à estética das ruínas. Em sua prosa, para além de Os sertôes, no qual o vínculo é bastante evidente, há muitos exemplos, mas sublinharei os seguintes textos:

- Do livro Contrastes e confrontos (1907), duas crônicas reportam-se ao ambiente das "cidades mortas", região decadente do vale do Paraíba, após a passagem vertiginosa do ciclo do café: "Fazedores de desertos" e "Entre as ruínas", em que uma espécie de crítica ecológica bem fundamentada a respeito do caráter predatório da cafeicultura faz contraponto ao desenho da paisagem natural e humana arruinada, com índices de abandono, desolação e melancolia. São textos da virada do século e Brito Broca sugeriu a possível forte influência que teriam tido sobre o imaginário de Monteiro Lobato e Godofredo Rangel, em obras posteriores (respectivamente, Cidades mortas, 1919 e Vida ociosa, 1920) ambientadas no mesmo clima e cenário.

- Do livro À margem da história (1909), conforme temos referido, pelo menos toda a primeira parte, que reúne os escritos amazônicos sob o título "Terra sem história". A esse conjunto devem ser agregados: o prefácio para o livro de contos de Alberto Rangel, Inferno verde (1908); o ensaio "Entre os seringais", publicado na revista Kosmos, em 1906, um dos mais radicais textos de denúncia do trabalho alienado dos seringueiros, não por acaso, depois, retomado pela imprensa operária como material de combate; o relatório da missão no Purus, também editado em 1906.

- Na marcha dos vulcanismos, embora de modo menos evidente, nos dois textos de Euclides dedicados a poetas - a conferência sobre Castro Alves e o prefácio ao livro Poemas e canções de Vicente de Carvalho, ambos de 1907 - encontrar-se-ão traços dessa atração pela fúria "milenária $\mathrm{e}$ geotetônica" dos elementos primevos, de uma realidade mostrada "vivamente monstruosa", de um "mar perseguidor" e de uma "terra prófuga", de um "chão que tumultua, e corre, e foge, e se crispa, e cai, e se alevanta" (18), brutalidades de todas as maneiras arruinadoras. 
- Na marcha de uma história nacional fantasmática, o conto-crônica "Numa volta do passado", saído na revista Kosmos, em 1908, faz da ruína de um velho sítio na região das "cidades mortas" o cenário de uma narrativa em retrospectiva da passagem fugaz da comitiva de D. Pedro, 80 anos antes, após o grito do Ipiranga. $\mathrm{O}$ arruinamento da paisagem real e a ilusão de um relato-sonho são marcados, no conto, pelas batidas martelantes e melancólicas de um monjolo, "pêndulo invertido" a marcar "todos os segundos atrasados de um século desaparecido" (19). Este é o texto talvez mais belo e visível de Euclides a propósito da fusão entre história e ruína, reportando-se a um "pessimismo patriótico-nacional" de base que recordará, sob diferentes registros, autores tão expressivos e distintos como Raul Pompéia, Gonzaga Duque, Machado de Assis, Lima Barreto e Capistrano de Abreu (no caso deste último, acorrem-me, sobretudo, as derradeiras páginas de Capitulos de história colonial, 1907, nas quais uma população dispersa vagueia sem rumo e arruinada, na busca de identidade histórico-cultural improvável).

- Complementariamente, vale lembrar ainda os textos dos relatórios sobre as ilhas de Búzios e Vitória (1902), em que desponta, mais uma vez, o tema da desolação da paisagem natural e humana; e sobre os reparos nas duas fortalezas de Bertioga (1904), em que o tema central é o da ruína do próprio empreendimento militar-colonial (20).

- Finalmente, fica o registro de sua crônica, ainda colegial, "Em viagem (folhetim)", de 1884, seu primeiro texto em prosa documentado, onde o narrador, descrevendo "impressões fugitivas das multicores e variegadas telas de uma natureza esplêndida que o tramway me deixa presenciar de relance quase", diante de imagens da expansão primaveril dos elementos, interrompe seu discurso com a adversativa que instaura, a partir dali, por toda a sua literatura, a nosso ver, traço romântico permanente e contraponto pesado a qualquer iluminismo civilizatório linear ou euforia quanto ao progresso técnico: “(...) contudo uma idéia triste nubla-me este quadro grandioso - lançando para a frente o olhar, avisto ali, curva sinistra, entre o claro azul da floresta, a linha da locomotiva, como uma ruga fatal na fronte da natureza... / Uma ruga, sim!... Ah! Tachem-me muito embora de antiprogressista e anticivilizador; mas clamarei sempre e sempre: - o progresso envelhece a natureza, cada linha do trem de ferro é uma ruga e longe não vem o tempo em que ela, sem seiva, mina$\mathrm{da}$, morrerá! E a humanidade (sic) não será dos céus que há de partir o grande 'Basta' (botem $b$ grande) que ponha fim a essa comédia lacrimosa a que chamam vida; mas sim de Londres; não finar-se-á o mundo ao rolar a última lágrima e sim ao queimar-se o último pedaço de carvão de 
pedra... / Tudo isto me revolta, me revolta vendo a cidade dominar a floresta, a sarjeta dominar a flor!" (21)

De modo por certo ingênuo, desenha-se, nessa escritura adolescente, matriz que depois iria se desdobrar sob figurações mais complexas, considerando-se não só a civilização técnica e seus aparelhos materiais e ideológicos como agentes arruinadores - incluindo-se, dentre eles, o próprio Estado e a instituição militar -, mas, de forma combinada, as forças brutas desencadeadas dos movimentos cósmicos e da evolução natural.

É meu intuito, porém, apontar, nestas notas, imagens da ruína dos mundos que se inscrevem, além da prosa euclidiana, na sua irregular e episódica produção de poesia, quase toda ela datada do século XIX, e feita entre os 17 e os 31 anos de idade. Manuel Bandeira, que selecionou dois sonetos de Euclides para a antologia de poetas brasileiros bissextos que organizou, em 1947, comenta, a esse respeito, que o autor mesmo "teria cedo reconhecido que o verso não seria nunca o seu apto instrumento de expressão literária". E arremata, considerando que, no inventor de Os sertões, "o poder transfigurador poético está é na sua prosa máscula, um tanto bárbara, às vezes, mas sempre magnífica" (22).

Talvez, para contrapor-se a uma prosa dita bárbara, só mesmo um poema rude. Para contextualizar um pouco mais nossa entrada no terreno desigual dessa poesia meio sem crédito, bem como nos meandros do referido poema, anexo (que localizei recentemente, numa folha do jornal Monitor Sul-Mineiro, da cidade de Campanha, Minas Gerais, de março de 1895, onde Euclides, antes de dar baixa definitiva do Exército, residiu por cerca de um ano), convém assinalar outros poemas em que o tema da caducidade precoce da experiência se insinua com mais força. Insisto em percorrer escritos tidos como menores por duas razões: para sugerir que o tema aqui abordado espraia-se de modo generalizado por toda a obra de Euclides; e para reverter o argumento da linguagem bárbara, de certa maneira um tanto recorrente na crítica euclidiana, a favor da hipótese norteadora de nosso trabalho: os barbarismos, rudezas e anfractuosidades em excesso do texto de Euclides indicam, por um lado, sua linhagem expressionista (a sugestão pioneira nesse rumo é de Gilberto Freyre) - constituindo, ao mesmo tempo, produto literário e invenção de estilo que traduzem, no plano da escrita, as brutalidades sem data, antigas e de agora; as ruínas à margem da história e as históricas; a permanente invasão da cultura pelos vampiros da razão; a ilusão de um mundo ordenado e inteiramente cognoscível; a realidade caótica do cosmos, sublime enquanto terrível e inapelavelmente precária.

Assim é que no poema "A cruz da estrada", de 1884, assinala-se o lugar desse símbolo sinistro, 
"Em meio das soidões...

(...)

Nos gélidos lugares

Em que ela se ergue, nunca o raio estala,

Nem pragueja o tufão... Hás de encontrá-la

Se acaso um dia nos sertões vagares... “ (23)

E, em "Último canto", da mesma época, manifesto poético contra a metrificação clássica, contra Castilho e Boileau, declara-se o amor a Musset e Hugo:

"Parar - é sublevar -

(...)

Esse arquiteto audaz do pensamento - Hugo -

Jamais sói refrear o seu verso terrível

Veloce como a luz, como o raio, incoercível!

Para, no mesmo poema, o eu lírico apresentar-se como jovem-velho, imagem que depois retornará:

"Não tenho ainda vinte anos

E sou um velho poeta... a dor e os desenganos

Sangraram-me mui cedo, a minha juventude

É como uma manhã de Londres - fria e rude..." (24)

Rudeza, neste caso, civilizada, recuperada numa variante de 1888 do mesmo poema, já intitulada "Fazendo versos" - em que a brutalidade do verso é assumida programaticamente:

"Que a crítica burguesa e honesta me perdoe:

Bem sei que isso faz mal - sei bem que isto lhe dói:

Que ela estigmatize a fronte e em raiva ingente

Arroje sobre mim a pecha: decadente!...

E vêde-me calcar do Pindo as áureas trilhas...

Colega!... hão de ser sempre essas canções estranhas

Umas selvagens filhas

Das miragens, dos céus, da luz e das montanhas!..." (25)

Configuração que se refaz, de modo mais condensado' e expressivo, no soneto "Mundos extintos", de 1886, um dos elencados por Bandeira, em que se esboça aliança clara e bela entre os mistérios da ciência e a verdade da poesia, questão sobre a qual Euclides se debruçaria nos últimos escritos de sua vida, vinte anos após, propugnando uma nova linguagem capaz de realizar essa difícil síntese: 
"Mundos extintos

(São tão remotas as estrelas que, apesar da vertiginosa velocidade da luz, elas se apagam, e continuam a brilhar durante séculos)

Morrem os mundos... Silenciosa e escura, Eterna noite cinge-os. Mudas, frias,

Nas luminosas solidões da altura

Erguem-se, assim, necrópoles sombrias...

Mas pra nós, di-lo a ciência, além perdura

A vida, e expande as rútilas magias...

Pelos séculos em fora a luz fulgura

Traçando-lhes as órbitas vazias.

Meus ideais! extinta claridade -

Mortos, rompeis, fantásticos e insanos

Da minh'alma a revolta imensidade...

E sois ainda todos os enganos

E toda a luz, e toda a mocidade

Desta velhice trágica aos vinte anos..." (26)

O eu lírico, que insiste em cantar seu envelhecimento precoce, demite-se de vez da possibilidade de prosseguir sua poética em versos e anuncia seu afastamento da forma-poema, depois de regressar da expedição silenciadora de Canudos. Por isso, o título de "Página vazia" a esse soneto de 1897, em que confessa:

"Quem volta da região assustadora

De onde eu venho, revendo, inda na mente,

Muitas cenas do drama comovente

De guerra despiedada e aterradora.

Certo não pode ter uma sonora

Estrofe ou canto ou ditirambo ardente

Que possa figurar dignamente

Em vosso álbum gentil, minha senhora.

(...)

Que quem mais tarde, nesta folha lesse

Perguntaria: 'Que autor é esse

De uns versos tão mal feitos e tão tristes?" (27)

Desnecessário será aqui enfatizar a modernidade do tema enfocado, que toca no empobrecimento da experiência e na função da arte num mundo belicamente convulso. De todo modo, temos aqui a significativa passagem do plano da assimetria dos tempos siderais e psicológicos para a contradição entre história 
e linguagem. O "Poema rude" pertence, acredito, a esse segundo plano, a essa vertente poético-dramática. Isso fica mais claro, de início, se lembrarmos que, na verdade, esse poema inédito forma um par historiográfico-literário, por si só prenhe de significados, com o famoso poema "As catas", único do autor igualmente datado de 1895 e também escrito quando de sua estadia na cidade de Campanha (e, posteriormente, dedicado a Coelho Neto). Em "As catas", cantam-se as ruínas do ciclo colonial da mineração, a paisagem desolada das vilas em abandono, a memória de riquezas perdidas,

"O fantasma de um povo que morreu."

Em vão, o eu lírico procura, no presente,

"Cidades que se ocultam majestosas

Na tristeza solene do sertão."

E, meditando sobre as ruínas da história colonial, sobre seu brilho efềmero que reaproxima a antigüidade do Oriente dos sertões mineiros, aconselha:

"Viajantes que rápidos passais

Pelas serras de Minas

Vindos de fulgurantes capitais,

Evitai as necrópoles sagradas,

Passai longe das ruínas,

Passai longe das Catas desoladas

Cheias de sombra, de tristeza e paz..." (28)

Para encerrar esse contraponto, desejo tão-somente fixar duas imagens que me ocorreram na leitura desse "Poema rude". Na preparação do motivo da tempestade, a paisagem embrutecida e tomada pelo tumulto e violência dos elementos, figura-se um cenário, assim:

"E a noite desce pavorosa... o assomo

Dos haustos da procela - rudes, maus.

Agrupa as nuvens em desordem, como

- A miniatura trágica do caos!”

Este derradeiro verso, dez anos depois, reaparecerá numa carta que Euclides escreverá de Manaus, no início de 1905, para Arthur Lemos, em Belém; e, igualmente retomada, surgirá de novo no texto do prefácio que ele fará ao livro Inferno verde, de Alberto Rangel, editado em Gênova no ano de 1908. Nestes casos, será a própria paisagem amazônica, como um todo, que aparecerá imaginada como uma "miniatura trágica do caos". Retornamos à brutalidade pré-histórica dos elementos originários do universo. 
De outra parte, chama a atenção, no poema, a figura do índio. Já é um índio acaboclado, camponês miserável de volta a seu "casebre branco", "choupana", "pobre lar honesto". A história nacional - afora o "imenso cataclismo" figurado na tempestade - já construíra, previamente, essa ruína. Românticorealista, na pena do poeta de ocasião e futuro prosador-símbolo, parece que aqui, nessa "canção estranha", "selvagem filha das miragens", várias rudezas e barbáries confluem: a da natureza cega e bruta; a do índio-camponês roubado em sua integridade cultural e no seu afeto; a do poeta, incapaz, diante da proximidade de tanta tragédia, de lapidar seus versos.

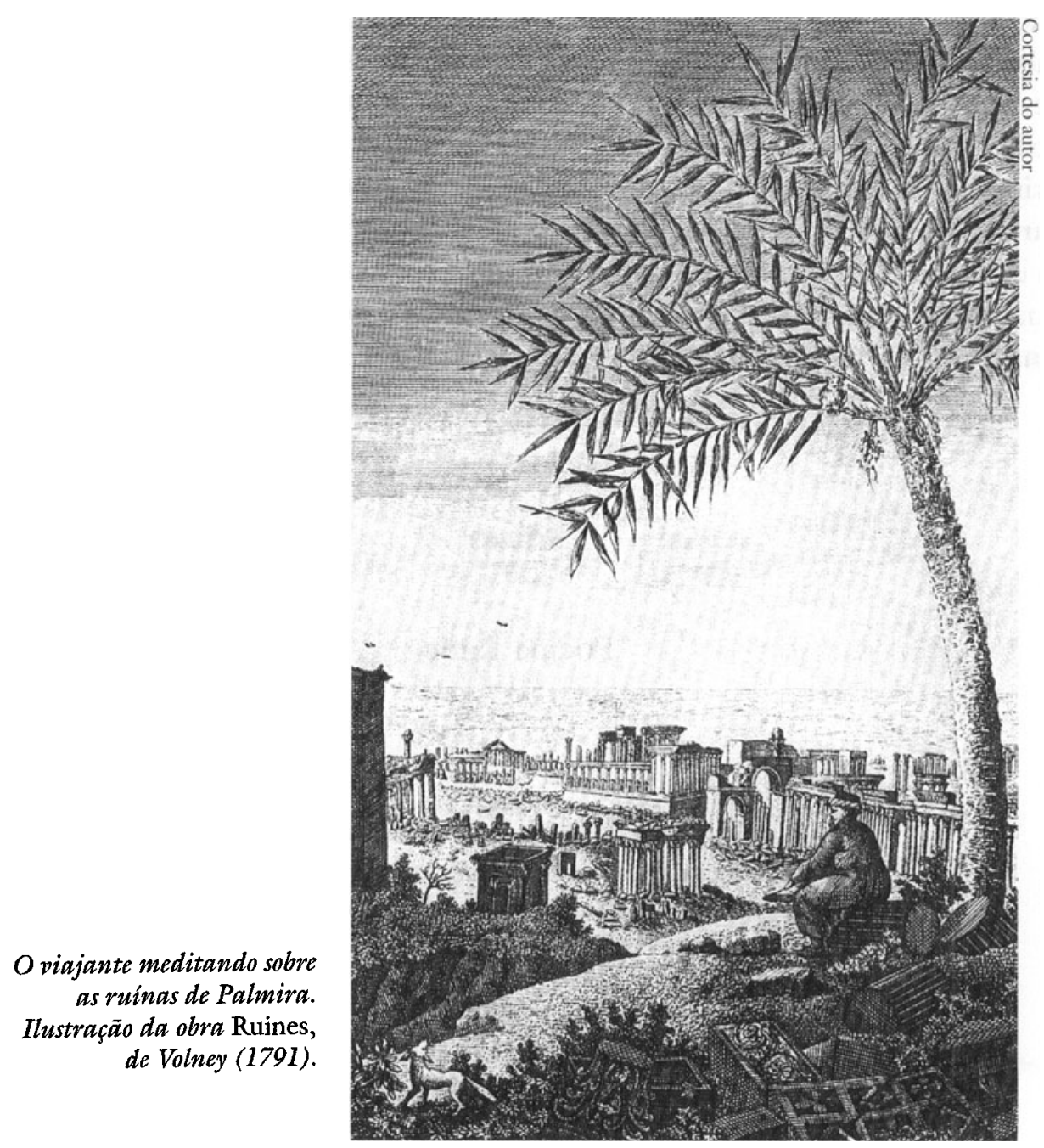

Nunca saberemos, afinal, que forma possuiria o manuscrito de "Brutalidade antiga", se Euclides levasse seu projeto a um termo, a uma solução literária mais acabada. Mas quis a história, ainda, deixar em aberto muitas portas para a tragédia. Se o manuscrito não pode ser decifrado em sua versão primitiva, 
descobrimos, ao menos, nessa página menor de um poema rude e, até aqui, mergulhado no esquecimento, palavras que, se repetem certo esquema convencional, são muito melhores do que a mera "página vazia". Ao lado das catas desoladas, antes da guerra final de Canudos, esse "poema rude" expressa a agudeza dessa voz vibrátil e hipnótica que já delineava, desde sempre, paisagens e dramas como verdadeiras "miniaturas trágicas do caos". Seu verbo poderoso assim representava o real de um país ilusório. Do sertão mineiro ao baiano, e deste ao amazônico, eram histórias de solidões seculares que se forjavam.

Seu futuro e principal narrador tinha sido também poeta passageiro. Mas não esquecera que a história, no mais das vezes, se construía como epos brutal. $\mathrm{E}$ sabia, acima de tudo, que as criações humanas - inclusive e, em especial, o processo civilizatório -, são por demais frágeis e de muito fácil destruição. Por isso, velho aos 20 anos, meditava tanto sobre as ruínas. Pois eram essas, enfim, as principais testemunhas do confronto natureza versus cultura e dos choques culturais humanos. Haveria que exprimir todo esse movimento numa língua "áspera e fremente". Penso que Euclides foi, entre raros autores, quem mais o logrou. Suas ruínas, que aqui re-situamos com a escavação desse "poema rude", assim o sinalizam.

\section{Anexo}

\section{Poema Rude}

(Ao Comendador Bernardo da Veiga)

Que tarde feia... sob um céu nubloso

O sol descamba - e rútilo, silente

Se embuça a pouco e pouco, vagaroso,

$\mathrm{Na}$ púrpura vastíssima do poente.

A terra toda apavorada treme,

Sentindo a convulsão que além se externa

No espaço, - aonde a tempestade freme

- Como um leão num antro de caverna...

Que tarde feia... imenso cataclismo

Imprime em tudo um rígido desmaio:

- Desce dos céus estranho hipnotismo

Nas vibrações elétricas do raio! 
Em tumulto, violentos, abalando( $\left.{ }^{*}\right)$

A terra, os ventos passam pelos ares...

Um Dies iroe aterrador entoando

Nas harpas majestosas dos palmares.

$\mathrm{E}$ a noite desce pavorosa... o assomo

Dos haustos da procela - rudes, maus.

Agrupa as nuvens em desordem, como

- A miniatura trágica do caos!

Reina o espanto e a mudez. A mais ferrenha

Fera, ante essa tormenta atroz que a assombra

Jaz a estas horas na mais funda brenha

Pávida e muda - tecer na sombra.

Mas no entretanto - que contraste! - em frente

A todo estrago que do céu deriva

Cinde os espaços, repentinamente

Alta e feliz uma canção, festiva...

Uma canção feliz! Quem é que segue

Tão descuidado assim pelas estradas,

Que uma canção festiva deixa entregue

De tal modo ao fragor das trovoadas?

O índio volta da caça - e inda distante.

Fita sorrindo o seu casebre branco,

Tão pobre mas tão alto! erguido adiante

Da branca serra sobre o abrupto flanco!

Em breve irá sanar - tranqüilo pensa -

Calcando da choupana a estreita trilha

De seu triste viver a agrura imensa

$\mathrm{Na}$ doce luz do olhar da pobre filha...

(*) "Em tumulto, violento, abalandos", no original: houve erro tipográfico evidente no caso da flexão do gerúndio. Já o plural conferido ao adjetivo "violento" garante a concordância e homologia com o substantivo "ventos", no verso seguinte. A ocorrência dessa troca do esse confirma-se adiante, quando toda essa quarta estrofe se repete incorporada à esfrofe $n^{\circ} 11$. 
E ligeiro caminha pelos campos...

E a tempestade erguendo a fronte aos céus

Envolta numa auréola de relampos,

Fulva - incendeia a catedral de Deus!

E em tumulto, violentos, abalando

A terra, os ventos passam pelos ares,

Um Dies iroe aterrador entoando

Nas harpas majestosas dos palmares!

Ele então pára - a contemplar, tremente,

A convulsão estranha do infinito...

Depois fita a choupana...

Asp'ro, fremente,

Em sua boca brônzea estala um grito!

Um raio ali tombara... mui mais lesto

Do que o tufão que nas quebradas freme

Chega ao local do pobre lar honesto

Mas ao chegar - apavorado - treme!

Jaz tudo em cinzas... que cruel desgraça!

Naquele peito quanta dor se ceva!

E sua filha? Uma lufada passa

E tudo que ele adora em frente leva...

Uma lágrima então - sangrenta e fria -

Extingue a luz do seu olhar sem calma:

- Última estrela - estrela que fugia

Da noite despovoada da sua alma...

E se empertiga heróico - da vingança

Empanam-lhe a razão os frios véus,

$O$ arco sopesa, para o largo avança:

" Tu vais morrer, Tupã! "

E frecha os céus...

(In: Monitor Sul-Mineiro. Campanha, MG, XXIV (1241), 27 mar.1895, p. 2).

\section{Notas}

I Cf., entre outros, Walnice Nogueira Galvão, Euclides, elite modernizadora e enquadramento. In: Euclides da Cunha. São Paulo, Ática, 1984, p. 7-37.

2 Tenho insistido sobre a necessidade de se reavaliar as raízes e as convenções do modernismo no Brasil, inclusive a ambígua categoria de pré-modernismo. Vide, a propósito, 
de minha autoria: Antigos modernistas. In: Tempo e História. São Paulo, Cia das Letras/Sec. Mun. Cult., 1992.

3 A expressão, aqui, é tomada de empréstimo a Fausto Cunha, no seu magnífico ensaio O romantismo no Brasil: de Castro Alves a Sousándrade. Rio de Janeiro, Paz e Terra, 1971.

4 No léxico de Os Sertões, organizado por Pedro A. Pinto, nota-se a recorrência dos termos "atraso", "retardatário", "tardio" e "seródio" para referir-se aos três séculos de descompasso histórico que separam tragicamente o mundo sertanejo da civilização metropolitana. Cf. P. A. Pinto, Os sertões de Euclides da Cunba: vocabulário e notas lexicológicas. Rio de Janeiro, Francisco Alves, 1930. Entre trabalhos que trataram pioneiramente dessa importante questão em Euclides, ver Nelson Omegna, Euclides da Cunha e a demora cultural. In: Arcádia. São Paulo, Fac. Direito/usP, ano X, n. 27, p. 23-32, out. 1945 .

5 Esta representação foi trabalhada no belo artigo de Walnice N. Galvão, Os sertões, o canto de uma cólera. In: Nossa América. São Paulo, Memorial da América Latina, n. 3, 1990, p. 88-103.

6 "Ruinaria", "ruína", "ruiniforme”, "restos", “destroços”, “decaído", “destruição" são algumas das ocorrências léxicas mais presentes no texto de Os sertões para designar essa atmosfera geral de desgaste e desolação. Cf. P. A. Pinto, op. cit.

7 “Construtores de ruínas" e “cidades errantes" são expressões euclidianas nos ensaios amazônicos que compõem a parte "Terra sem história" de seu último livro: $\dot{A}$ margem da história (1909). Inspirei-me nessas imagens para montar o capítulo "Vertigem do vazio" (cap. 4), em Trem fantasma: a modernidade na selva. São Paulo, Cia das Letras, 1988. Cf. também meu artigo: Os sertões amazônicos de Euclides, baseado em conferência dada na Semana Euclidiana de 1989, em São José do Rio Pardo e publicado no jornal Amazonas em Tempo, Manaus, 3 maio 1992 (Supl. Cultura em Dia, p. 1).

8 Carta a Coelho Neto, Manaus, 10 mar. 1905. In: Obra completa, v. II. Rio de Janeiro, Aguilar, 1966.

9 Firmo Dutra, Euclides da Cunha: um capítulo da sua vida. In: Correio da Manhã, 6 fev. 1938. Apud E. Cunha, Um paraiso perdido: ensaios, estudos e pronunciamentos sobre a Amazônia (Org.: L. Tocantins). Rio de Janeiro, José Olympio, 1986.

10 Cf. C.-F. Volney, Voyage en Egypte et en Sirie (ed.orig.: 1787); c Les ruines, ou méditation sur les répolutions des empires (ed. orig.: 1791). Cf. E. Burke, A philosophical inquiry into the origin of our ideas of the sublime and beautiful (ed. orig.: 1757-59). Sobre arte, ruína e solidão, ver: Francis D. Klingender, Arte y revolución industrial, Madri, Cátedra, 1983; e Eduardo Subirats, Paisagens da solidão, São Paulo, Duas Cidades, 1986.

11 Sobre a repercussão de Volney no século XIX, de resto intensa, ver: Roland Mortier, La poétique des ruines en France: ses origines, ses variations de la Renaissance à Victor Hugo. Genebra, Droz, 1974. Sobre a presença significativa desse filósofo francês na 
obra de Hegel, embora não assumida - em particular no tocante ao tema central da prosa da história se constituindo a partir da reflexão sobre as ruínas - ver os interessantes comentários de Jacques D'Hondt em Hegel secret, 2ª ed., Paris, PUF, 1986, p. 83-113. Quanto ao hugonismo no Brasil, cf. A. Carneiro Leão, Victor Hugo no Brasil. Rio de Janeiro, José Olympio, 1960. Este autor recupera o seguinte poema de Euclides da Cunha publicado no jornal Quinzenal, Rio de Janeiro, 9 jun. 1885, a propósito da morte de Victor Hugo:

"O Mestre

Não choremo-lo não ... se essas dores supremas

Geram sombria noite em nosso ser magoado

Em nossa alma se arqueia

Cada folha imortal de seus imensos poemas

Como um céu constelado

Desses eternos sóis: o canto, a estrofe e a idéia." (op. cit., p. 180).

Este poema, de resto importante na configuração do romantismo euclidiano, não foi incorporado à Obra completa editada pela Aguilar em 1966.

12 Sobre a recepção de Les ruines nos EUA da virada do vXIII para o XIX, cf. Gilbert Chinard, Volney et l'Amérique. Baltimore/Paris; The Johns Hopkins Press/PUF, 1923. Domingo Sarmiento, em Facundo o civilización y barbarie (1845) constrói uma paisagem arruinada e oriental em torno dos pampas, inspirada diretamente em Volney. Taunay cita Volney no elenco de suas leituras: este e outros aspectos da relação entre história, memorialismo e ficção na obra do autor de Inocência vêm sendo pesquisados por Maria Lídia Maretti, orientanda do programa de doutorado em teoria literária do IEL/Unicamp. Se em $A$ retirada da Laguna; há traços evidentes do binômio história-ruína, na sua narrativa histórica $A$ cidade do ouro e das ruínas, cuja primeira edição data de 1891, contando o episódio da morte do pintor e tio Adrien Taunay no rio Guaporé, numa Vila Bela já decadente do ciclo aurífero, durante a malfadada expedição Langsdorff, as afinidades com a linhagem de Volney são profundas.

13 "Como Volney e Chateaubriand, Buckle dirigiu-se ao Oriente, atraído pela esfinge que ali guarda o segredo do passado da humanidade. As ruínas majestosas das cidades destruídas, as tradições arqui-seculares dos impérios extintos e das religiões que se transformaram, a sublimidade do deserto só comparável à sublimidade do oceano, as descobertas arqueológicas, recompondo os povos, os costumes, as guerras, as civilizações enfim, adormecidas, sob o peso dos séculos, tudo isso fascinava o espírito melancólico e insaciável de Buckle, com o encanto empolgador do desconhecido..." (J.C. Gomes Ribeiro, "Henrique Thomaz Buckle". In: H.T. Buckle, Historia da Civilização na Inglaterra, São Paulo, Typ. da Casa Ecletica, 1900, p. CxxxIV).

14 Cf. Raul Pompéia, Vulcão extinto. In: Cançães sem metro. Rio de Janeiro, Aldina, 1900. Cf. Gonzaga Duque, Revoluções brazileiras (resumos históricos). Rio de Janeiro, Typ. "Jornal do Commercio", 1898. Cf. Alberto Rangel, "Pitoresco e estafa (?)" (crônica inédita de viagem a Nápoles e ao Vesúvio, 1908), Arquivo Nacional, AP/54.

15 Cf. Silva Jardim, Memóriase viagens: I - campanha de um propagandista (1887-1890). Lisboa, Typ. da Companhia Nacional Ed., 1891.

16 Cf. Oliveira Lima, Recordaçõés pessoais. In: Por protesto e adoração, Rio de Janeiro, 
Grêmio Euclydes da Cunha, 1919. Cf. Araripe Jr., Dois vulcões extintos (sobre as mortes de Raul Pompéia e Euclides). In: Obra crítica (v. IV, 1901-1909). Rio de Janeiro, MEC/Casa de Rui Barbosa, 1966, p. 291-299.

17 Baseio-me na interessante discussão sobre as tradições marxista e geopolítica no entendimento da dialética natureza versus história proposta por Richard James Blackburn em O vampiro da razão: um ensaio de filosofia da bistória. São Paulo, Unesp, 1992. Sobre a presença do caos e do acaso no pensamento estético-científico de Euclides, remeto a outro artigo de minha autoria: "Estrelas indecifráveis ou: um sonhador quer sempre mais", publicado na obra coletiva Utopia e modernidade, Curitiba, UFPR, 1994. “Tumulto", "tumultuar", "tumultuariamente" e "tumultuário" estão entre os signos preferidos de Euclides para designar cenários instáveis e realidades indeterminadas, "à margem da história". Cf. P.A. Pinto, op. cit.

18 E. Cunha, Antes dos versos. In: Obra completa, v. I, p. 442-443. Vide nota anterior.

19 E. Cunha, $O C, \mathrm{I}, \mathrm{p} .453-456$.

20 Id., ibid., p. 465-480. Sobre a viagem às ilhas de Búzios e Vitória, Vicente de Carvalho, que acompanhou Euclides, narra seu caráter acidentado, em meio a uma tempestade e quase-naufrágio. Cf. "Euclides da Cunha". In: Revista da Academia Brasileira de Letras, Rio de Janeiro, ano Xxx, n. 92, p. 428-430, ago. 1929. Quando a caminho do Amazonas, em fins de 1904, numa escala nordestina, Euclides visitou os portos de Recife e Cabedelo, tendo, neste último, se impressionado com as ruínas da fortaleza de Santa Catarina. Cf. Ademar Vidal, Euclydes em Recife e Cabedelo. In: Dom Casmurro, Rio de Janeiro, X, p. 439-440, maio 1946, p. 56.

21 E. Cunha, $O C, \mathrm{I}$, p. 517.

22 Id., ibid., p. 629.

23 Id., ibid., p. 637. Cf. também p. 531-532, onde, num fragmento de um caderno de notas de Lorena, 1902, reaparece o tema das "santas cruzes" numa estrada precária rumo a São Luís do Paraitinga.

24 Id., ibid., p. 639-640.

25 Id., ibid., p. 642-643. Sobre Hugo, cf. nota 11, supra.

26 Id., ibid., p. 650.

27 Id., ibid., p. 656.

28 Id., ibid., p. 652-653. O original da versão dedicada a Coclho Neto, em 1903, encontra-se no Setor de Manuscritos da Biblioteca Nacional. A primeira versão impressa desse belo poema, salvo engano, apareceu na Revista da Academia Brazileira de Letras, ano II, n. 5, p. 56-58, 1911. O texto publicado na Obra completa possui vários erros evidentes, quando em cotejo com o manuscrito ou a referida edição. Este constitui, talvez, o texto mais modelar de Euclides com vista ao binômio história-ruína. Ecos de Volney (mediados por Sarmiento?) despontam claramente nas imagens de "Babilônias, Bagdás pagãs", "muçulmano austero ou de um templário / Diante de Meca ou de Jerusalém”, “Amplas mesquitas, vastos mausoléus”. Enfim, deserto su- 
blime de cujas miragens ruinosas pode erguer-se a meditação histórico-legendária sobre "A coorte febril dos Bandeirantes". Rudeza anônima e arcaica, produtora de heroicidade:

"Nas construções amplíssimas,

Que as contemplando eu penso na rudeza

De uma raça já morta de titãs.

E abandonadas... no entretanto, quem

As observa, no extremo

Dos horizontes afastados, tem

O religioso espanto e o extraordinário

Exxtase supremo".

\section{Resumo}

Este artigo analisa um dos aspectos menos enfatizados nas interpretações correntes sobre a obra de Euclides da Cunha: sua filiação às tendências estéticas e à concepção de mundo do Romantismo, muito marcante na literatura e cultura brasileiras da segunda metade do século XIX. Na busca dessas raízes, recupera-se, de modo sumário, o roteiro de uma poética das ruínas e seu vínculo estreito com a própria visão da História em Euclides, cujas figurações remontam a Volney, no fim do século XVIII, e a V. Hugo, mais proximamente ao autor de Os sertões. Tais afinidades são indicadas em textos menos estudados de Euclides, entre os quais "Poema rude", escrito em 1895, em Campanha, Minas Gerais, e não-incluído em sua Obra completa.

\section{Abstract}

This article analyses one of the least emphasized aspects in the current interpretation of Euclides da Cunha's work, his affiliation with the asthetic trends and world views of Romanticism, remarkably present in Brazilian literature and culture during the second half of the nineteenth century. In the quest for those roots, we retrace briefly the traveled road of a "poetics of ruins" and its close connection with the author's eighteenth century and, closer to the author of Os sertões (Rebellion in the backlands), to Victor Hugo. Such affinities are pointed in some of Euclides da Cunha's least studied texts, among which "Poema rude" (Rough poem), written in 1895 at Campanha, Minas Gerais, and not included in his Obra completa (Complete work).

Francisco Foot Hardman é professor do Instituto de Estudo da Linguagem (IEL)da Universidade Estadual de Campinas (Unicamp). É autor, entre outros, de Nem pátria, nem patrão: vida operária e cultura anarquista no Brasil (Brasiliense, 1983) e de Trem fantasma: a modernidade na selva (Companhia das Letras, 1988).

Versão preliminar deste texto foi apresentada pelo autor no seminário da Área de História Cultural realizado em 25 de março de 1994 no IEA-USP. 